Civil War written by his professorial son Michael.

Leon D. Epstein

University of Wisconsin-Madison

\section{Julian F. S. Foster}

Julian Foster, professor emeritus at California State University, Fullerton, passed away summer of 2003. Julian's 31-year career at CSUF was one of great accomplishment in many diverse ways. He was a superb teacher of Political Philosophy and American Politics, known for imposing high standards on his students and requiring analytical thinking within the best traditions of his Oxford and UCLA education. He was also a scholar of note. His edited book and several publications dealing with student activism and University politics were important contributions to that literature in its early stages. His most widely read piece, a monograph entitled None Dare Call It Reason, written to counter a notorious right wing tract, was widely circulated and received much national publicity.

His most important contributions however were as an advocate of the facultyrun University. A fearless foe of administrative rule, he worked to insure faculty governance as CSUF expanded from a largely teachers college to the present multi-phased University. An expert in the logic and craft of University legislation, he wrote policies and procedures that insured faculty control of the personnel process and academic freedom. As chair of the political science department from 1978 to 1984 , he championed high academic standards and clearly defined rules for promotion and tenure. Three times he chaired the University Academic Senate, using it as a forum for the rights of the faculty. A skilled politician, he gained the respect of key administrators and was able to accomplish his goals without overt confrontation. The result was often referred to within the system as the "Fullerton way": strong faculty governance with genial concurrence from a respectful, if leery administration.

Julian leaves his wife of 45 years, Beatrice, and three children. He is sorely missed by his colleagues and the University community.

J. Vincent Buck and Alan Saltzstein California State University, Fullerton

\section{Stanley Mazer}

Dr. Stanley Mazer, professor and chairman of the Allied Human Services at Baltimore City Community College, died in Baltimore, Maryland on January 13, 2003 after an extensive battle against infection following a kidney transplant. At age 68, he had been a member of the APSA for more than 25 years. He is survived by his wife of 30 years, Dr. Marianne Githens, TODD Distinguished Professor of Political Science at Goucher College in Towson, Maryland, sons Jeffrey Mazer of Chicago, Jonathon Githens Mazer of London, England, daughters Sharon Mazer Nealon of Gort Lauderdale, Florida and Julie Mazer Lee of Parkston, Maryland, as well as one granddaughter, Rachel.

Professor Mazer, along with his wife Marianne, was a regular participant in annual APSA program deliberations for the past three decades and served on the APSA Departmental Chairpersons Committee.

Born in Brooklyn, New York, July 20, 1934, Stanley earned his undergraduate degree from Braudeis University in 1956, followed by a Masters in Social Work from Adelphi and Doctorate in Urban Education from the University of Maryland-College Park. Most of his professional life was spent in Baltimore-a city he grew to love and serve.

His initial position was as a social worker at the Jewish Community Center in the early 1960s. By 1963 he was hired by then-Mayor Phillip H. Goodman as the city's first director of human renewal, with the task of focusing attention on people displaced by urban renewal programs. By 1965 he had become director for neighborhood development for the Community Action Agency.

As he joined the ranks of academia, Stanley brought a wealth of experience from his years in community welfare and development. During those community action years he was reported to have often "tangled with" fellow welfare officials and other decision makers as he pushed for a law that would prohibit "renting inadequate houses to welfare recipients" thereby supporting slum lords and disagreed with a site chosen for the location of the University of Maryland-Baltimore County because it would "hold down" African-American students. As a public administrator, he was widely regarded as having a great empathy and concern for people who were disadvantaged. He often spoke of the need for government to step in to make life different for those who did not have much in terms of worldly goods.

At Baltimore County Community College, Mazer served as a classroom teacher, departmental chair, Dean of the Social Services Division, and Vice President for Academic Affairs. Colleagues describe him as an excellent educator with real vision and a knack for looking at and relating issues to course content. His expectations of students were said to be "high" and he gave them vision and purpose. They also labeled him "all inclusive-having the ability to bring people of diverse cultures and interests together."

Dr. Mazer served on the APSA's Departmental Chairperson's Committee; his work with that committee represents a successful venture in bridging the gap between political education in community colleges and four-year institutions.

Friends and acquaintances recall Stanley's special warmth and charm with persons of all ages, even upon first encounters. He could put persons at ease, individually or collectively. This trait served him and his institution well in efforts to reach an urban student clientele. He frequently walked his dog through the park and handed out applications to the unemployed sitting on benches. Choosing to live in older homes in the City of Baltimore, Mazer stated, "I have found that most cities worry about facades, the main streets. The way to evaluate a city, I think, is from the back-go to the alleys for a true test of its strength."

Dr. Mazer spent his free time drawing, painting, and doing sculpture. These works of art are found throughout his home.

One student, commenting on Stanley's death, in a letter to Marianne, wrote, "Stanley Mazer made a choice about how to live and through his passing leaves and incredible void, believers and skeptics alike saw a vision of what is possible when one lives what one believes. Your husband clearly built bridges, tore down walls and in so doing, changed lives."

On a personal note, Stanley was a warm and engaging friend, and excellent and accommodating host, and a loving, supportive husband, in addition to his role as an able social science scholar, competent innovative academic administrator, and an extraordinary human being. He was a man of great passion and quick wit.

When one spent an evening of discussion and interaction with Marianne and Stanley at home, one experienced not only and interesting and engaging exchange, but also a kind of examination of a variety of issues and concerns covering the total human experience.

James J. Prestage, a retired University Chancellor who knew Mazer as a 